\title{
STUDI PROSEDUR PELELANGAN PENGADAAN JASA KONSULTAN PADA PROYEK PEMERINTAH MENURUT KEPPRES NO. 80 TAHUN 2003
}

\author{
Maksum Tanubrata $^{1}$, Merianti Elisabeth Hutagalung ${ }^{2}$ \\ 1,2 Jurusan Teknik Sipil, Universitas Kristen Maranatha \\ Jl. Prof. drg. Soeria Sumantri, MPH., No. 65, Bandung, 40164 \\ telp. (022) 2012186, fax. (022) 2017622 \\ Email : maksum.tanubrata@eng.maranatha.edu
}

\begin{abstract}
ABSTRAK
Studi ini dilakukan dengan tujuan untuk memahami tahapan - tahapan pelaksanaan pengadaan jasa konsultan pengawas pada proyek pemerintah dan membandingkannya dengan tahapan - tahapan pelaksanaan dengan KEPPRES No.80 Tahun 2003 yang merupakan pedoman pelaksanaan pengadaan barang/jasa pemerintah. Tahapan - tahapan pelelangan pada umumnya adalah pengumuman diadakan lelang, pendaftaran, pengambilan dan pengembalian dokumen lelang, penjelasan pekerjaan, pemasukan penawaran, pembukaan penawaran, pengumuman peringkat teknis, penetapan pemenang, masa sanggahan oleh peserta, klasifikasi dan negosiasi, keputusan pemenang lelang dan penandatanganan kontrak. Studi kasus diambil dari proyek Peningkatan Pusat Pengembangan Penataran Guru ( PPPG ) Teknologi Bandung, Jl.Pesantren Km.2 Cibabat Cimahi dengan pekerjaan pengawasan. Konsultan pemenang adalah PT.Arjasari Primaraya, dengan waktu pelaksanaan yang direncanakan adalah 290 hari kalender. Setiap tahap yang dilakukan oleh panitia pelelangan pada proyek Peningkatan PPPG dianalisis dan disesuaikan dengan KEPPRES No.80 Tahun 2003 apakah sudah sesuai dengan petunjuk teknis pada KEPPRES No.80 Tahun 2003 atau tidak. Secara garis besar setiap tahap yang dilakukan oleh panitia lelang telah sesuai dengan petunjuk teknis KEPPRES no.80 Tahun 2003. Berdasarkan analisis dan pembahasan dapat diambil kesimpulan bahwa prosedur pelelangan perencanaan pada proyek Peningkatan PPPG Teknologi Bandung sangat sesuai dengan KEPPRES No.80 tahun 2003, walaupun ada syarat yang tidak dilakukan oleh panitia.
\end{abstract}

Kata kunci: Pelaksanaan, Pelelangan, Keppres 80 tahun 2003.

\begin{abstract}
This Study is conducted as a mean to comprehend step by step execution of levying of supervisor consultant service at government project and compare him with step by step execution with KEPPRES No.80 Year 2003 is guidance of execution of levying of goods / governmental service. Step by step auction in general is announcement performed by auction, registration, intake and return of auction document, explanation of work, inclusion of offer, opening of offer, announcement of technical peringkat, stipulating of winner, a period of to expostulation by participant, negotiation and classification, decision of winner auction and signing of contract. Case study taken away by the project of Improvement Of Center Development Of Upgrading Of Teacher ( PPPG ) Technological of Bandung,Jl.Pesantren Km.2 Cibabat Cimahi with work of observation. Winner consultant is PT.ARJASARI Primaraya, with execution time the planned is 290 calender day. Each every phase conducted by auction committee at project is Make-Up of PPPG analysed and adapted for KEPPRES No.80 Year 2003 , what have as according to technical guide at KEPPRES No.80 Year 2003 or not. Marginally each;every phase conducted by committee auction have as according to technical guide of No.80 Year KEPPRES 2003. Pursuant to solution and analysis can be taken conclusion that procedure auction of planning at project is Make-Up Of Technological PPPG of Bandung very as according to KEPPRES No.80 year 2003, despite of un conducted condition by committee.
\end{abstract}

Keywords: Execution, Auction, Keppres 80 year 2003. 


\section{PENDAHULUAN}

Pada masa kebangkitan kembali dari keterpurukan ekonomi di negara kita, maka pemerintah memulai pembangunan dan perbaikan disegala bidang. Perkembangan wilayah dan kota di Indonesia berlanjut seiring dengan majunya jaman. Namun dalam hal perkembangan dan pembangunannya ternyata tidak terlepas dari berbagai tantangan yaitu bagaimana mewujudkan pembangunan agar tercipta masyarakat yang adil dan makmur dan pemerataan pembangunan di pusat dan daerah untuk menghindari ketidakpuasan masyarakat daerah serta agar terlaksananya program pemerintah daerah yang dikenal saat ini yaitu “Otonomi Daerah” dalam hal pemerataan pembangunan disegala bidang.

Pemerintah harus melewati tantangan tersebut di tengah krisis ekonomi yang belum usai dan ketidakpastian politik serta peristiwa-peristiwa alam yang mengguncang Negara Republik Indonesia yang sangat membutuhkan perhatian dari pemerintah baik pusat maupun daerah.

Pemerintah juga dituntut untuk lebih transparan dalam menjalankan tugasnya dan membersihkan diri serta para jajarannya dari unsure korupsi,kolusi dan nepotisme. Oleh sebab itu masyarakat diajak untuk turut terlibat dalam proses pelaksanaan pembangunan .

Maksud dari penulisan ini adalah untuk mengetahui proses pelelangan/ prosedur atau tata cara pelaksanaan lelang konsultan pada proyek-proyek pemerintah (studi kasus gedung asrama PPPG). Tujuan yang diharapkan dari penulisan ini adalah untuk menjelaskan mengenai tahap-tahap pelaksanaan lelang/ tender konsultan yang dilakukan dan dilaksanakan oleh pemerintah berdasarkan KEPPRES No. 80 Tahun 2003.

\section{TINJAUAN LITERATUR}

\subsection{Kualifikasi dan Penggolongan Jasa Konsultan}

Adapun kualifikasi jasa konsultan menurut INKINDO ( Ikatan Nasional Konsultan Indonesia ) ditetapkan berdasarkan kemampuan nilai kontrak, yaitu:

1. K-Kecil: s.d Rp. 200.000.000,00 (dua ratus juta rupiah).

2. M-Menengah: Rp. 200.000.000,00 (dua ratus juta rupiah) sampai dengan Rp. 1.000.000.000,00 (satu miliar rupiah).

3. B-Besar: di atas Rp. 1.000.000.000,00 (satu miliar rupiah).

Kegiatan kualifikasi konsultan ialah penilaian serta penggolongan konsultan menurut tingkat kemampuan dasarnya pada setiap bidang, sub-bidang, dan lingkup pekerjaan. 
Penilaian terhadap kemampuan dasar dan profesionalisme konsultan dapat dilihat pada Tabel 1.

Tabel 1. Penilaian terhadap kemampuan dasar dan profesionalisme konsultan

\begin{tabular}{|c|c|c|c|c|c|}
\hline $\mathrm{No}$. & $\begin{array}{c}\text { Kriteria } \\
\text { Penilaian }\end{array}$ & Golongan 1 & Golongan 2 & Golongan 3 & Ket. \\
\hline 1. & Pengalaman & $\begin{array}{l}\text { Konsultan yang } \\
\text { pernah } \\
\text { melaksanakan } \\
\text { pekerjaan dengan } \\
\text { cara dan hasil baik } \\
\text { sebanyak } 3 \text { yang } \\
\text { masing - masing } \\
\text { bernilai diatas lima } \\
\text { puluh juta. Bobot = } \\
15\end{array}$ & $\begin{array}{l}\text { Konsultan yang } \\
\text { pernah melaksanakan } \\
\text { pekerjaan dengan cara } \\
\text { dan hasil baik } \\
\text { sebanyak } 3 \text { yang } \\
\text { masing - masing } \\
\text { bernilai sampai } \\
\text { dengan lima puluh } \\
\text { juta. Bobot = } 10\end{array}$ & $\begin{array}{l}\text { Konsultan } \\
\text { yang belum } \\
\text { berpengalaman } \\
\text {. Bobot }=5\end{array}$ & \\
\hline 2. & Tenaga Ahli & $\begin{array}{l}\text { Jumlah nilai tenaga } \\
\text { ahli diatas } 1000 . \\
\text { Bobot }=75\end{array}$ & $\begin{array}{l}\text { Jumlah nilai tenaga } \\
\text { ahli di antara } 700 \text { dan } \\
1000 . \\
\text { Bobot }=60\end{array}$ & $\begin{array}{l}\text { Jumlah nilai } \\
\text { tenaga ahli di } \\
\text { antara } 50 \text { dan } \\
699 . \\
\text { Bobot }=45\end{array}$ & $\begin{array}{l}\text { Kepala = } \\
100 \\
\text { Utama = } \\
75 \\
\text { Muda = } \\
30 \\
\text { Teknisi } \\
=10\end{array}$ \\
\hline 3. & Keuangan & $\begin{array}{l}\text { Konsultan yang } \\
\text { memiliki kekayaan } \\
\text { bersih dengan nilai } \\
\text { di atas Rp.100 juta. } \\
\text { Bobot }=5 .\end{array}$ & $\begin{array}{l}\text { Konsultan yang } \\
\text { memiliki kekayaan } \\
\text { bersih dengan nilai di } \\
\text { atas Rp. } 25 \text { juta. } \\
\text { sampai dengan Rp. } \\
100 \text { juta. } \\
\text { Bobot }=5 \text {. }\end{array}$ & $\begin{array}{l}\text { Konsultan } \\
\text { yang memiliki } \\
\text { kekayaan } \\
\text { bersih dengan } \\
\text { nilai antara } \\
\text { Rp. } 5 \text { juta } \\
\text { sampai dengan } \\
\text { Rp.25 juta } \\
\text { Bobot = } 3 \text {. }\end{array}$ & \\
\hline
\end{tabular}

Perhitungan kekayaan bersih didasarkan pada penilaian neraca keuangan terakhir dan laporan keuangan lainnya dengan berpedoman pada rumusan sebagai berikut :

$$
\text { Kekayaan bersih }=(a+b+c)-(d+e)
$$

dimana: $\mathrm{a}=$ aktiva lancar

$$
\begin{aligned}
& \text { b }=\text { aktiva tetap } \\
& c=\text { aktiva lainnya } \\
& \text { d }=\text { utang jangka pendek } \\
& \text { e }=\text { utang jangka panjang }
\end{aligned}
$$

Konsultan digolongkan atas A, B, dan C yang ditentukan atas dasar jumlah bobot yang dapat dikumpulkan. Penetapannya adalah sebagai berikut:

1. Golongan A : $89-100$ 
2. Golongan B : $68-88$

3. Golongan C : $56-67$

Penggolongan nilai pekerjaan jasa konsultansi yang dapat dilaksanakan oleh tiap tiap kualifikasi adalah sebagai berikut :

1. Golongan A di atas Rp. 100 juta.

2. Golongan B di atas Rp. 50 juta sampai dengan Rp. 100 juta.

3. Golongan C sampai dengan Rp. 50 juta.

\subsection{Sumber-sumber Hukum Pelelangan}

Peraturan yang mengatur pelaksanaan pelelangan di Indonesia diatur oleh Keputusan Presiden Republik Indonesia tentang Pelaksanaan Anggaran dan Belanja Negara ( Keppres tentang Pelaksanaan APBN ). Keppres yang mengatur pengadaan barang dan jasa telah beberapa kali mengalami penyempurnaan, contohnya Keppres No.14 A Tahun 1980, tanggal 14 April 1980 disempurnakan menjadi Keppres No.18 Tahun 1981, tanggal 5 Mei 1981. Tahun anggaran 1984/1985 telah dikeluarkan Keppres No.29 Tahun 1984, tanggal 21 April 1984 sebagai pengganti Keppres No.14 A Tahun 1980 dan Keppres No.18 Tahun 1981. Kemudian disempurnakan kembali dengan dikeluarkannya Keppres No.16 Tahun 1994 dilanjutkan Keppres No.6 Tahun 1999. Kemudian disempurnakan kembali dengan dikeluarkannya Keppres No.18 Tahun 2000 , Keppres No.80 Tahun 2003., dan terakhir Keppres no 8 tahun 2006.

\subsection{Prosedur Pelelangan Berdasarkan KEPPRES No. 80 Tahun 2003}

Dengan semakin berkembangnya ilmu pengetahuan dan teknologi mengakibatkan Pemerintah harus memperbaharui peraturan-peraturan mengenai pedoman pelaksanaan pengadaan barang/jasa yang ada agar dapat lebih membantu masyarakat mengenai tata cara pelaksanaan atau pengadaan barang/jasa. Oleh karena itu Pemerintah memperbaharui KEPPRES No.18 Tahun 2000 dengan mengeluarkan KEPPRES No.80 Tahun 2003, lalu perbaikan Keppres No 80 dengan Keppres no 8 tahun 2006.

\subsubsection{Persyaratan Penyedia Barang Atau Jasa}

Persyaratan penyedia barang/jasa dalam pelaksanaan pengadaan adalah sebagai berikut:

1. Memenuhi peraturan perundang-undangan untuk menjalankan usaha/kegiatan sebagai penyedia barang/jasa. 
2. Memiliki keahlian, pengalaman, kemampuan teknis dan manajerial untuk menyediakan barang/jasa.

3. Tidak dalam pengawasan pengadilan, tidak pailit, kegiatan usahanya tidak sedang dihentikan, dan/atau direksi yang bertindak untuk dan atas nama perusahaan tidak sedang dalam menjalani sanksi pidana.

4. Secara hukum mempunyai kapasitas menandatangani kontrak.

5. Sebagai wajib pajak sudah memenuhi kewajiban perpajakan tahun terakhir, dibuktikan dengan melampirkan fotokopi bukti tanda terima penyampaian Surat Pajak Tahunan ( SPT ), Pajak Penghasilan ( PPh ) tahun terakhir, dan fotokopi Surat Setoran Pajak ( SSP ) PPh pasal 29.

6. Dalam kurun waktu 4 ( empat ) tahun terakhir pernah memperoleh pekerjaan menyediakan barang/jasa baik di lingkungan pemerintah maupun swasta termasuk pengalaman subkontrak, kecuali penyedia barang/jasa yang baru berdiri kurang dari 3 ( tiga ) tahun.

7. Memiliki sumber daya manusia, modal, peralatan, dan fasilitas lainnya yang diperlukan dalam pengadaan barang/jasa.

8. Tidak masuk dalam daftar hitam instansi pemerintah manapun.

9. Memiliki alamat tetap dan jelas serta dapat dijangkau dengan pos.

10. Khusus untuk penyedia barang/jasa orang perorangan persyaratannya sama dengan di atas kecuali huruf $\mathrm{f}$.

11. Pegawai negeri, pegawai BI, pegawai BHMN, BUMN, BUMD dilarang menjadi penyedia barang/jasa, kecuali yang bersangkutan mengambil cuti di luar tanggungan Negara/BI/BHMN/BUMN/BUMD.

12. Penyedia barang/jasa yang keikutsertaannya menimbulkan pertentangan kepentingan dilarang menjadi penyedia barang/jasa. Yang dimaksud dengan pertentangan kepentingan antara lain:

a. Penyedia barang/jassa yang telah ditunjuk sebagai konsultan perencana tidak boleh menjadi penyedia barang/jasa pemborongan untuk pekerjaan fisik yang direncanakan.

b. Penyedia barang/jasa yang ditunjuk sebagai konsultan pengawas tidak boleh menjadi penyedia barang/jasa pemborongan untuk pekerjaan fisik yang diawasi.

13. Terpenuhnya persyaratan penyedia barang/jasa dinilai melalui proses prakualifikasi atau pascakualifikasi oleh panitia/pejabat pengadaan.

14. Termasuk dalam penyedia barang/jasa yang sesuai dengan nilai paket pekerjaan. 
15. Memiliki surat dukungan keuangan dari bank pemerinatah/swasta untuk mengikuti pengadaan barang/jasa sekurang-kurangnya $10 \%$ dari nilai proyek/kegiatan untuk pekerjaan jasa pemborongan dan $5 \%$ untuk pekerjaan pemasokan barang/jasa lainnya, kecuali untuk penyedia barang/jasa usaha kecil termasuk koperasi kecil.

\subsubsection{Penyusunan Harga Perkiraan Sendiri}

Pengguna barang/jasa wajib memiliki harga perkiraan sendiri ( HPS ) yang dikalkulasikan secara keahlian dan berdasarkan data yang dapat dipertanggungjawabkan. Data yang digunakan sebagai dasar penyusunan HPS antara lain sebagai berikut:

1. Harga pasar setempat menjelang dilaksanakannya pelaksanaan.

2. Informasi biaya satuan yang dipublikasikan secara resmi oleh Badan Pusat Statistik (BPS), asosiasi terkait dan sumber data lain yang dapat dipertanggungjawabkan.

3. Daftar biaya/tarif barang/jasa yang dikeluarkan oleh agen tunggal atau pabrikan.

4. Biaya kontrak sebelumnya yang sedang berjalan dengan mempertimbangkan factor perubahan biaya, apabila terjadi perubahan biaya.

5. Daftar biaya standar yang dikeluarkan oleh instansi yang berwenang.

HPS disusun oleh panitia/pejabat pengadaan dan ditetapkan oleh pengguna barang/jasa. HPS digunakan sebagai alat untuk menilai kewajaran harga penawaran termasuk rinciannya dan untuk menetapkan besaran tambahan nilai jaminan pelaksanaan bagi penawaran yang dinilai terlalu rendah, tetapi tidak dapat dijadikan dasar untuk menggugurkan penawaran. Nilai total HPS terbuka dan diumumkan sejak rapat penjelasan lelang, sedangkan rincian HPS tidak boleh dibuka dan bersifat rahasia.

\subsubsection{Persiapan Pelaksanaan Pemilihan Jasa Konsultansi}

Pengguna barang/jasa menyusun Kerangka Acuan Kerja ( KAK ) dan menunjuk panitia pengadaan/pejabat pengadaan. Panitia/pejabat pengadaan menyusun Harga Perkiraan Sendiri ( HPS ) dan dokumen pemilihan penyedia jasa konsultansi meliputi KAK, syarat administrasi, syarat teknis, syarat keuangan, metoda pemilihan penyedia jasa konsultansi, metoda penyampaian dokumen penawaran, metoda evaluasi penawaran, dan jenis kontrak yang akan digunakan.

\subsubsection{Metoda Pemilihan Penyedia Jasa Konsultansi}

Pemilihan penyedia jasa konsultansi pada prinsipnya harus dilakukan melalui seleksi umum. Dalam keadaan tertentu pemilihan penyedia jasa konsultansi dapat dilakukan melalui 
seleksi terbatas, seleksi langsung atau penunjukan langsung. Seleksi umum adalah metoda pemilihan penyedia jasa konsultansi yang daftar pendek pesertanya dipilih melalui proses prakualifikasi secara terbuka yaitu diumumkan secara luas melalui media massa dan papan pengumuman resmi untuk penerangan umum sehingga masyarakat luas mengetahui dan penyedia jasa konsultansi yang berminat dan memnuhi kualifikasi dapat mengikutinya. Pengumuman penyedia jasa konsultansi harus dapat memberikan informasi kepada masyarakat luas, terutama penyedia jasa konsultansi baik dari daerah setempat maupun dari daerah lainnya.

Seleksi terbatas adalah metoda pemilihan penyedia jasa konsultansi untuk pekerjaan yang kompleks dan diyakini jumlah penyedia jasa yang mampu melaksanakan pekerjaan tersebut jumlahnya terbatas. Dalam hal metoda seleksi umum atau seleksi terbatas dinilai tidak efisien dari segi biaya seleksi, maka pemilihan penyedia jasa konsultansi dapat dilakukan denganb seleksi langsung yaitu metoda pemilihan penyedia jasa konsultansi yang daftar pendek pesertanya ditentukan melalui proses prakualifikasi terhadap penyedia jasa konsultansi yang dipilih langsung dan diumumkan sekurang - kurannya di papan pengumuman resmi untuk penerangan umum atau media elektronik ( internet ).

Dalam keadaan tertentu dan keadaan khusus, pemilihan penyedia jasa konsultansi dapat dilakukan dengan menunjuk satu penyedia jasa konsultansi yang memenuhi kualifikasi dan dilakukan negosiasi baik dari segi teknis maupun biaya sehingga diperoleh biaya yang wajar dan secara teknis dapat dipertanggungjawabkan.

\subsubsection{Posedur Pemilihan Penyedia Jasa Konsultansi}

Prosedur pemilihan penyedia jasa konsultansi dengan metoda seleksi umum, yaitu meliputi: metoda evaluasi kualitas dan metoda dua sampul.

a. Pengumuman prakualifikasi.

b. Pengambilan dokumen prakualifikasi.

c. Pemasukan dokumen prakualifikasi.

d. Evaluasi prakualifikasi.

e. Penetapan hasil prakualifikasi.

f. Pengumuman hasil prakualifikasi.

g. Masa sanggah prakualifikasi.

h. Undangan kepada konsultan yang masuk daftar pendek.

i. Pengambilan dokumen seleksi umum.

j. Penjelasan 
k. Penyusunan berita acara penjelasan dokumen seleksi dan perubahannya.

l. Pemasukan penawaran.

m. Pembukaan penawaran administrasi dan teknis ( sampul I ).

n. Evaluasi administrasi dan teknis.

o. Penetapan peringkat teknis.

p. Pemberitahuan/pengumuman peringkat teknis ( pemenang ).

q. Masa sanggah.

r. Pembukaan penawaran harga ( sampul II ) peringkat teknis terbaik.

s. Klarifikasi dan negosiasi teknis dan biaya.

t. Penunjukan pemenang.

u. Penandatangan kontrak.



Gambar 1. Tahap-tahap prakualifikasi pelelangan berdasarkan 
KEPPRES No. 80 Tahun 2003

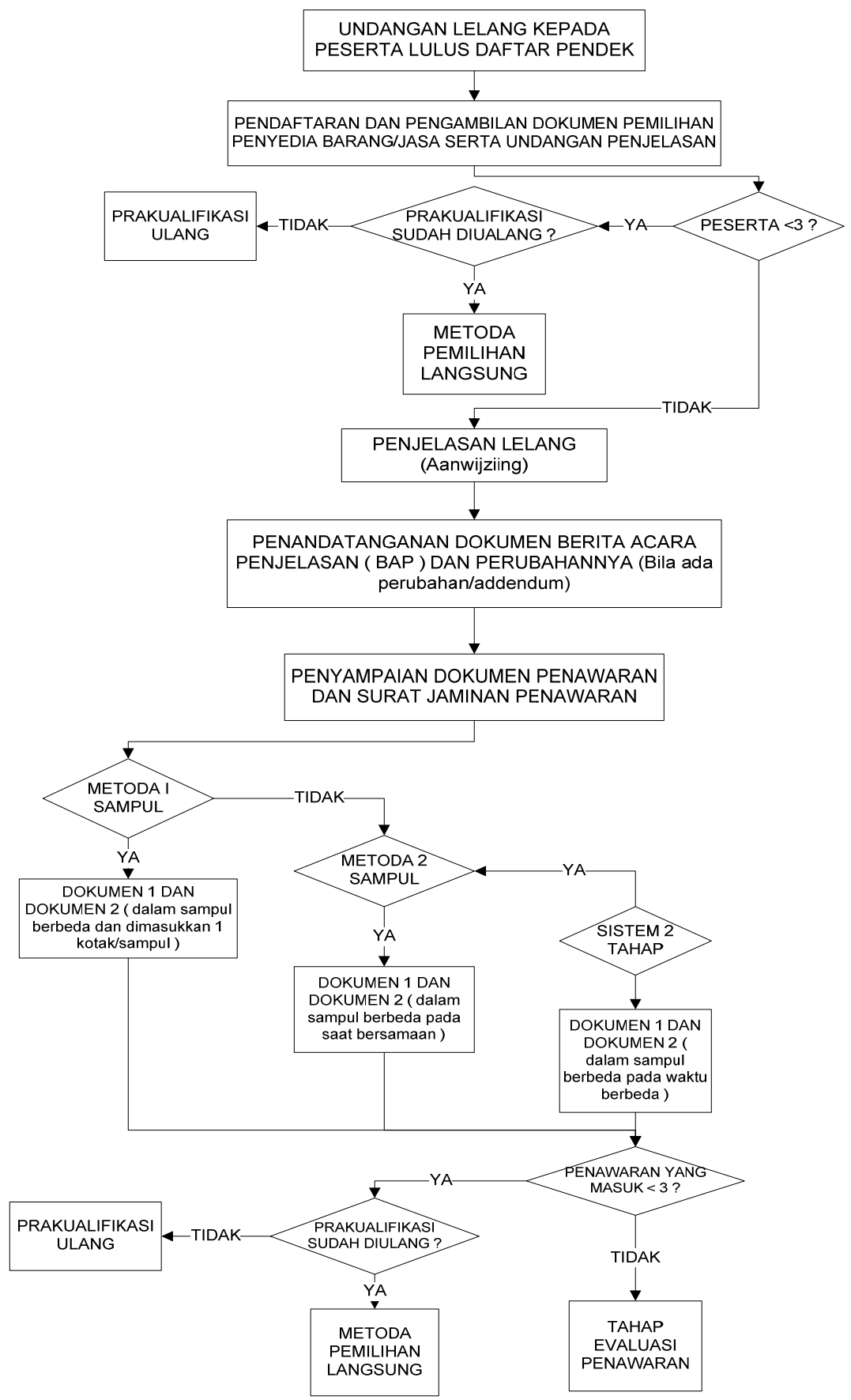

Gambar 2. Tahap - tahap pemasukkan dan penyampaian dokumen penawaran berdasarkan KPPRES No. 80 Tahun 2003

\section{STUDI KASUS DAN PEMBAHASAN}

Berdasarkan hasil analisis tahapan - tahapan pelelangan yang berdasarkan pada KEPPRES No.80 Tahun 2003 maka dapat dibahas hal - hal sebagai berikut: 


\section{Pengumuman Prakualifikasi}

Pada pelelangan jasa konstruksi untuk proyek Peningkatan Pusat Pengembangan Penataran Guru Teknologi Bandung, pengumuman prakualifikasi ditempel pada tanggal 17 Mei 2004 pada papan pengumuman resmi yang terdapat di Kantor Proyek Peningkatan PPPGT Bandung dan juga melalui DPD INKINDO pada tanggal 17 Mei 2004 untuk diketahui oleh masyarakat luas dan badan usaha yang berminat.

Hal ini sesuai dengan KEPPRES No.80 Tahun 2003 bahwa pengadaan barang/jasa atau pelelangan dilakukan secara terbuka dengan pengumuman secara luas melalui media cetak dan papan pengumuman resmi untuk penerangan umum serta jika memungkinkan melalui media elektronik, sehingga masyarakat atau dunia usaha yang berminat dan memenuhi syarat dapat mengikutinya. Pada KEPPRES No.80 Tahun 2003 lebih merinci jangka waktu pengumuman prakualifikasi yaitu selambat - lambatnya 7 ( tujuh ) hari kerja dan jangka waktu pengambilan formulir prakualifikasi yaitu selambat - lambatnya 9 ( sembilan ) hari kerja.

\section{Proses Prakualifikasi}

Pada tanggal 31 Mei 2004 panitia pelelangan Pengembangan dan Pembangunan Gedung Asrama dan Pendidikan PPPG Teknologi Bandung mengadakan rapat pemeriksaan persyaratan administrasi berdasarkan dokumen prakualifikasi yang diminta dari 6 ( enam ) rekanan yang mendaftar.

Panitia memutuskan dari 6 ( enam ) rekanan yang mengambil dokumen prakualifikasi, 5 ( lima ) rekanan yang memenuhi persyaratan dan 1 ( satu ) rekanan dinyatakan tidak memenuhi persyaratan karena tidak memasukkan dokumen prakualifikasi sampai pada batas waktu yang ditentukan.

Hal ini sesuai dengan KEPPRES No.80 Tahun 2003 bahwa pad proses prakualifikasi panitia pengadaan/pelelangan melakukan pemeriksaan kelengkapan dokumen dan ketentuan ketentuan yang telah ditetapkan sebelumnya terhadap para peserta lelang yang telah mendaftarkan diri.

\section{Pengumuman Para Pemenang Prakualifikasi}

Setelah dilakukan pemeriksaan terhadap para peserta lelang maka hal selanjutnya yang dilakukan panitia pelelangan adalah mengumumkan hasil prakualifikasi yaitu dari 6 ( enam ) rekanan yang mengambil dokumen dan 5 ( lima ) yang memasukkan dokumen prakualifikasi, 5 ( lima ) rekanan yang memenuhi persyaratan dan 1 ( satu ) rekanan dinyatakan tidak memenuhi persyaratan karena tidak memasukkan dokumen sampai pada batas akhir waktu pemasukkan dokumen. Untuk peserta yang lulus prakualifikasi dapat 
mengambil Dokumen Seleksi Umum dan Undangan Penjelasan Pekerjaan ( aanwijzing ) setelah tidak adanya sanggahan dari para peserta lelang dan bagi peserta yang tidak lulus prakualifikasi, panitia menyampaikannya melalui surat pemberitahuan yang dikirim ke alamat peserta yang tidak lulus.

Pada KEPPRES No.80 Tahun 2003 selain membahas mengenai pengumuman bagi calon peserta lelang yang lulus tahap prakualifikasi juga membahas mengenai apabila ada peserta yang tidak setuju dengan hasil prakualifikasi dapat mengajukan sanggahan kepada pengguna barang/jasa.

Maka pada tahap ini sangat sesuai dengan KEPPRES No.80 Tahun 2003 karena setelah pengumuman prakualifikasi panitia pelelangan memberikan masa sanggah kepada peserta lelang.

\section{Penjelasan Pekerjaan}

Penjelasan pekerjaan dilaksanakan pada tanggal 17 Juni 2004 dengan mengundang para peserta yang telah masuk dalam daftar pendek yang mencakup penjelasan administrasi dan teknis.

Hal ini sesuai dengan KEPPRES No.80 Tahun 2003 bahwa penjelasan lelang dilakukan di tempat dan waktu yang telah ditentukan, dihadiri oleh para calon penyedia barang/jasa yang terdaftar dalam daftar pendek, yang sekurang - kurangnya mencakup penjelasan:

a. Nama Proyek adalah Proyek Pengembangan dan Renovasi Gedung Asrama Pendidikan PPPG Teknologi Bandung.

b. Jenis dan lokasi pekerjaan adalah Pengawasan Pengembangan dan Renovasi Gedung Asrama Pendidikan PPPG Teknologi Bandung Jl. Pasantren Km.2 Cibabat, Kota Cimahi.

c. Pemberi tugas adalah Departemen Pendidikan Nasional Direktorat Jendral Pendidikan Dasar dan Menengah Pusat Pengembangan Penataran Guru Teknologi ( PPPGT ) Bandung.

d. Konsultan Perencana.

e. Panitia Lelang yang ditunjuk oleh pimpinan proyek.

f. Kontraktor.

g. Dokumen Lelang

h. Pemasukan dan Pembukaan Surat Penawaran Harga waktunya ditetapkan hari Jumat, tanggal 25 Juni 2004 jam 10.00 WIB bertempat di Ruang Rapat PPPG Teknologi Bandung Jalan Pasantren Km.2 Cibabat, Kota Cimahi. 


\section{Pemasukan dan Pembukaan Dokumen Administrasi dan Teknis}

Penawaran dilakukan dengan metode 2 ( dua ) sampul dimana sampul pertama berisi dokumen administrasi dan teknis, sampul kedua berisi dokumen penawaran harga/biaya.

Hal ini sesuai dengan KEPPRES No.80 Tahun 2003 bahwa panitia pelelangan dapat memilih salah satu dari 3 metode penyampaian dokumen penawaran yang harus ditetapkan dalam dokumen lelang yaitu:
a. Metode Satu Sampul
b. Metode Dua Sampul
c. Metode Dua Tahap

\section{Evaluasi Administrasi dan Teknis}

Pada hari Selasa tanggal 29 Juni 2004 , panitia menyelenggarakan rapat pengevaluasian terhadap dokumen penawaran administrasi dan teknis.

Tata cara penilaiannya adalah sebagai berikut: Penetapan calon pemenang dengan cara penelitian terhadap bobot penilaian unsur - unsur sebagai berikut:

a. Pengalaman Perusahaan Konsultan

b. Pendekatan dan Metodologi

c. Kualifikasi Tenaga Ahli

Dari hasil penelitian kelengkapan administrasi dan teknis menunjukkan bahwa dari 5 ( lima ) perusahaan peserta pelelangan yang memasukkan penawaran ternyata semua peserta pelelangan dinyatakan telah memenuhi syarat.

Hal ini sesuai dengan KEPPRES No.80 Tahun 2003 bahwa pelaksanaan evaluasi administrasi dan teknis dilakukan oleh panitia terhadap semua penawaran yang dinyatakan lulus pada saat pembukaan penawaran, metode dan tata cara evaluasi yang telah ditetapkan dalam dokumen lelang.

\section{Penetapan dan Pengumuman Peringkat Teknis}

Setelah evaluasi administrasi dan teknis, maka panitia pelelangan dapat menetukan urutan calon pemenang berdasarkan nilai bobot yang diperoleh masing - masing perusahaan. Panitia pelelangan lalu memberitahukan /mengumumkan kepada peserta pelelangan peringkat teknis masing - masing perusahaan.

Hal ini sesuai dengan KEPPRES No.80 Tahun 2003 bahwa berdasarkan evaluasi penaawaran teknis, panitia/pejabat pengadaan menetapkan urutan konsultan yang dituangkan dalam berita acara evaluasi penawaran teknis dan hasil evaluasi teknis telah ditetapkan oleh pengguna jasa konsultansi disampaikan kepada seluruh peserta. 


\section{Pembukaan Penawaran Harga/Biaya ( Sampul II )}

Panitia mengundang para peserta lelang yang telah lulus evaluasi teknis untuk mengikuti penawaran biaya ( sampul II ) pada tanggal 2 Juli 2004. Pada hari itu juga panitia menyatakan bahwa Pemasukan Surat Penawaran Harga ditutup dan panitia mencocokkan peserta dengan daftar hadir. Ketua panitia menunjuk seorang anggota Panitia dan peserta diminta untuk membuka sampul penawaran harga dan Dokumen Penawaran Harga tersebut sesuai dengan ketetapan KEPPRES No.80 Tahun 2003.

Ketua panitia membentuk panitia kecil yang terdiri dari seorang anggota panitia dan 2 ( dua ) orang wakil dari peserta kemudian para anggota panitia yang hadir meneliti bersama surat penawaran harga yang yang diterima untuk menetapkan sah atau tidaknya penawaran tersebut.

Setelah melakukan penelitian ternyata seluruh dokumen penawaran yang siajukan peserta seleksi langsung adalah sah dan besarnya penawaran harga sudah memenuhi persyaratan sesuai dengan ketentuan dalam KEPPRES No.80 Tahun 2003.

\section{Evaluasi Biaya dan Perhitungan Kombinasi Usulan Teknis dan Biaya}

Pada hari Sabtu tanggal 03 Juli 2004 , bertempat di Ruang Sidang Wisma Pangrayungan PPPG Teknologi Bandung, panitia mengadakan penelitian terhadap surat penawaran harga dan mengadakan perhitungan kombinasi antara penawaran teknis dan biaya.

Penelitian dan evaluasi dilakukan terhadap 5 ( lima ) rekanan yang telah sah dan memenuhi syarat. Dasar - dasar perhitungan/penilaian yang dipergunakan adalah sabagai berikut :

1. Perhitungan/penilaian dilakukan berdasarkan rumus yang terdapat dalam KEPPRES No.80 Tahun 2003.

2. Harga Penawaran yang diterima tidak boleh mengandung kesalahan yang fatal baik dalam perincian, perhitungan, perkalian maupun penjumlahan.

Setelah dilakukan penelitian terhadap harga penawaran maka selanjutnya dilakukan penetuan peringkat calon pemenang berdasarkan pada jumlah nilai akhir tiap unsur yang dinilai.

\section{Pengusulan Penetapan Pemenang}

Berdasarkan nilai tertinggi yang diperoleh dari hasil perhitungan kombinasi teknis dan biaya serta sesuai dengan KEPPRES No.80 Tahun 2003, maka panitia segera melakukan usulan calon pemenang kepada Pimpinan Proyek Peningkatan PPPGT Bandung serta negosiasi teknis dan biaya dengan konsultan peringkat pertama agar diperoleh biaya yang wajar yaitu kepada PT. Arjasari Primaraya, sehingga pada tahap ini telah sesuai dengan KEPPRES No.80 Tahun 2003. 


\section{Penetapan Calon Pemenang}

Pimpinan Proyek Peningkatan PPPGT Bandung pada tanggal 6 Juli 2004 menyetujui usul panitia pengadaan dan menetapkan calon pemenang/pelaksana Pekerjaan Pengawasan Pengembangan Pembangunan Gedung Asrama Pendidikan PPPGT Bandung dengan memperhatikan ketentuan - ketentuan yang berlaku di Indonesia dan pemenangnya adalah PT. Arjasari Primaraya.

Pada KEPPRES No.80 Tahun 2003 yang menetapkan calon pemenang adalah pengguna barang/jasa atas usul dari panitia pengadaan yang menguntungkan bagi negara, dalam arti :

1. Penawaran memenuhi syarat administrasi dan teknis yang ditentukan dalam dokumen.

2. Perhitungan harga yang ditawarkan adalah yang terendah dan yang responsif..

3. Telah memperhatikan penggunaan semaksimal mungkin hasil produksi dalam negeri.

Sehingga dalam hal ini sesuai dengan KEPPRES No.80 Tahun 2003.

\section{Pengumuman Pemenang}

Pada tanggal 7 Juli 2004 panitia pengadaan mengumumkan pemenang lelang yaitu PT. Arjasari Primaraya.

Hal ini sesuai dengan KEPPRES No.80 Tahun2003 bahwa pemenang lelang diumumkan dan diberitahukan oleh panitia/pejabat pengadaan kepada peserta selambat - lambatnya 2 ( dua ) hari kerja setelah penetapan pemenang oleh pimpinan proyek.

\section{Masa Sanggah}

Kepada peserta lelang yang keberatan atas penetapan pemenang lelang, dapat mengajukan sanggahan kepada Pimpinan Proyek Peningkatan PPPGT Bandung selambat - lambatnya tanggal 12 Juli 2004.

Hal ini sesuai dengan KEPPRES No.80 Tahun 2003 bahwa bila ada peserta lelang yang keberatan atas penetapan pemenang lelang diberi kesempatan untuk mengajukan sanggahan secara tertulis yang berdasarkan ketentuan yang terdapat dalam KEPPRES. Pengajuan sanggahan dilakukan selambat - lambatnya 5 ( lima ) hari kerja setelah pengumuman pemenang.

\section{Klarifikasi dan Negosiasi Teknis dan Biaya dengan Pemenang}

Pada hari Selasa tanggal 13 Juli 2004 panitia mengadakan klarifikasi dan negosiasi teknis dan biaya dengan pemenang terhadap penawaran teknis dan biaya yang diajukan pemenang. 
Dengan berpedoman kepada ketentuan dari Petunjuk Teknis pelaksanaan Keppres No. 80 Tahun 2003, maka Panitia Lelang dan Seleksi Konsultan melakukan klarifikasi dan negosiasi teknis dan harga yang diajukan oleh Konsultan Pengawas (Calon Penyedia Jasa Pengawasan) dengan memperhatikan 3 ( tiga ) aspek yang perlu dinegosiasi yaitu :

1. Kesesuaian rencana kerja dengan jenis pengeluaran biaya.

2. Volume kegiatan dan jenis pengeluaran.

3. Harga satuan dibandingkan dengan harga yang berlaku dipasaran/kewajaran harga. Hasil Klarifikasi teknis adalah sesuai dengan Kerangka Acuan Kerja ( KAK ), sedangkan hasil negosiasi adalah alokasi waktu pekerjaan adalah 290 ( dua ratus sembilan puluh ) hari kerja dan hasil negosiasi penawaran biaya adalah dari penawaran sebesar Rp. 73.794.600,- ( Tujuh puluh tiga juta tujuh ratus sembilan puluh empat ribu enam ratus rupiah ) menjadi Rp. 72.754.00,- ( Tujuh puluh dua juta tujuh ratus lima puluh empat ribu rupiah ).

Berdasarkan petunjuk teknis KEPPRES No.80 tahun 2003, apabila dengan pemenang pertama tidak terdapat kesepakatan maka dilakukan klarifikasi dan negosiasi teknis dan biaya dengan pemenang kedua dan ketiga sampai terjadi kesepakatan di antara kedua belah puhak.

Pada Proyek Peningkatan PPPGT Bandung ini terjadi kesepakatan antara pemenang pertama dangan panitia pengadaan jadi tidak perlu diadakan klarifikasi dan negosiasi teknis dan biaya dengan pemenang kedua ataupun ketiga, hal ini sesuai dengan KEPPRES No.80 Tahun 2003.

\section{Penunjukan Pemenang Lelang ( SPPBJ )}

Pada tanggal 14 Juli 2004 panitia pengadaan menyatakan bahwa setelah didapat kesepakatan dalan klarifikasi teknis dan biaya dengan pemenang pertama sehingga panitia memutuskan setuju atas hasil tersebut bahwa PT. Arjasari Primaraya ditunjuk sebagai pelaksana Pekerjaan Pengawasan Proyek Pengembangan PPPGT Bandung berdasarkan pemilihan pemenang pelelangan umum yang dilakukan pada tangga 11 Juni 2004.

Pada KEPPRES No.80 tahun 2003 membahas bahwa Pengguna barang/jasa mengeluarkan Surat Penunjukan Penyedia Barang/Jasa ( SPPBJ ) sebagai pelaksana pekerjaan lelang, dengan ketentuan :

1. Tidak ada sanggahan dari peserta lelang

2. Sanggahan yang diterima pejabat yang berwenang tidak benar, atau sanggahan diterima melewati masa sanggah.

Peserta lelang yang ditetapkan sebagai penyedia barang/jasa wajib menerima keputusan tersebut. 


\section{Penandatanganan Kontrak}

Pada hari Senin tanggal 19 Juli 2004 terjadi penandatanganan kontrak kerja antara pemimpin proyek ( Pemberi Kerja ) sebagai pihak pertama dengan PT. Arjasari Primaraya sebagai Penyedia Barang/Jasa ( Konsultan ) sebagai pihak kedua, dimana tugas pekerjaan yang akan dilaksanakan oleh pihak kedua sebagaimana yang tercantum di dalam Kerangka Acuan Kerja ( KAK ).

Hal ini sesuai dengan KEPPRES No.80 Tahun 2003 bahwa para pihak menandatangani kontrak selambat - lambatnya 14 ( empat belas ) hari kerja terhitung sejak diterbitkannya Surat Keputusan Penetapan Penyedia Barang/Jasa ( SPPBJ ).

\section{KESIMPULAN}

Setelah mengevaluasi dan menganalisa prosedur pelelangan konsultan pada proyek pemerintah yaitu proyek Peningkatan PPPGT Bandung untuk Pekerjaan Pengawasan Pengembangan dan Pembangunan Gedung Asrama Pendidikan PPPG Teknologi Bandung berdasarkan KEPPRES No.80 Tahun 2003, maka diperoleh kesimpulan bahwa hal dasar yang harus diperhatikan dalam tahapan - tahapan yang dilakukan oleh panitia adalah realisasi dari keseluruhan perencanaan, baik dari segi teknis, administrasi serta manajemennya, dan dapat disimpulkan sebagai berikut:

1. Panitia pada pelelangan ini mengalami proses dari pelelangan umum menjadi pelelangan terbatas dengan metode Seleksi Langsung dimana:

Panitia menyaring dari 6 ( enam ) peserta yang mengambil formulir lelang berdasarkan :
a. Pernyataan Minat
b. Pernyataan Tidak Dalam Masalah Hukum
c. Data Umum
d. Surat Ijin usaha Jasa Konsultan ( SIUJK )
e. Landasan Hukum
f. Komisaris ( PT )
g. Direksi
h. Kepemilikan Saham
i. Data Pelunasan Kewajiban Pajak
j. Kemampuan Fasilitas dan Personalia
k. $\quad$ Pengalaman 4 Tahun Terakhir 
1. Pekerjaan Yang sedang Dilaksanakan

m. Tidak Masuk Daftar Hitam

n. Memiliki Kemampuan Dasar

Maka terpilihlah 5 peserta yang masuk dalam Daftar Pendek. Dari kelima peserta yang Masuk Daftar Pendek maka pada saat pengumuman prakualifikasi kelima peserta tersebut lulus pada tahap prakualifikasi dan dapat mengambilan undangan penjelasan pekerjaan dan dokumen seleksi umum.

2. Pada proses pelelangan jasa konsultansi pada proyek Pengembangan dan Pembangunan Gedung Asrama Pendidikan PPPG Teknologi Bandung ini mengalami 2 ( dua ) kali masa sanggah yaitu setelah pengumuman prakualifikasi dan setelah pengumuman pemenang, hal ini sangat sesuai dengan petunjuk teknis KEPPRES No.80 Tahun 2003.

3. Pada tahap pengumuman prakualifikasi, panitia lelang seleksi jasa konsultansi pengawasan tidak mengumumkan secara luas atau tidak mengumumkan melalui media cetak atau elektronik tetapi hanya pada papan pengumuman resmi dan melalui INKINDO tetapi sudah sesuai dengan petunjuk teknis KEPPRES No.80 Tahun 2003.

4. Pada proses pelelangan proyek Pengembangan PPPG Teknologi Bandung tidak ada tahap yang dihilangkan atau yang terlewatkan oleh panitia.

5. Tahapan - tahapan pelelangan yang dilakukan oleh Panitia Lelang Seleksi Jasa Konsultansi Pengawasan pada proyek Peningkatan PPPG Teknologi Bandung secara garis besar telah sesuai dengan KEPPRES No.80 Tahun 2003, karena panitia melaksanakan pelelangan berdasarkan petunjuk teknis KEPPRES No.80 Tahun 2003.

\section{PUSTAKA}

1. Imam Soeharto, (2001). Manajemen Proyek, Edisi Kedua, Penerbit Erlangga, Jakarta.

2. Istimawan Dipohusodo, (2001). Manajemen Proyek dan Konstruksi, Penerbit Kanisius, Yogyakarta.

3. KEPPRES No.80 Tahun 2003, (2003). Tentang Pedoman Pelaksanaan Pengadaan Barang/Jasa Pemerintah, Penerbit Karina, Surabaya.

4. Tanubrata, T., (2004), Diktat Kuliah Manajemen Konstruksi, Fakultas Teknik Jurusan Sipil, Universitas Kristen Maranatha, Bandung. 